Litinfinite Journal

ISSN: 2582-0400 [Online]

CODEN: LITIBR

Vol-2, Issue-1 ( $2^{\text {nd }}$ July, 2020)

Page No: 54-61

DOI: 10.47365/litinfinite.2.1.2020.54-61

Section: Interview

\title{
An interview with poet Ashwani Kumar
}

\author{
Sreetanwi Chakraborty \\ Assistant Professor \\ Amity Institute of English Studies and Research \\ Amity University Kolkata \\ Email I.d.: schakraborty3@kol.amity.edu
}

\begin{abstract}
This is an interview with Indian English poet Ashwani Kumar who talks about poetry, Indian English and the middle-class aesthetics versus the contemporary Indian English poetry segment. He talks at large about his relationship to poetry, the changes in the realms of Indian English poetry, and the current trends that have marked the poetic geniuses here. English and its original colonial hangover and using English for everyday use-there is also discussion about travelling, how it is related to poetry, and the insurgent desires and dreams that are some of the most major components of every poet's mind and writing spirit. The translational and transnational aspect of writing also finds special reference in the interview.
\end{abstract}

Keywords: Poetry, Indian English Poems, Indian Poetry, World Poetry, Aesthetics

Ashwani Kumar is Mumbai- based Indian English poet, writer, and professor at Tata Institute of Social Sciences (Mumbai) His anthologies "My Grandfather's Imaginary Typewriter" with a prolegomenon by Ashis Nandy and 'Banaras and the Other' have been published by Yeti Books and Poetrywala. His poems-translated in several languages are noted for 'lyrical celebration' of garbled voices of memory and their subversive 'whimsy' quality. His "Banaras and the Other", first of a trilogy, was long listed for 1stJayadev National Poetry Award 2017. Recently, award-winning Hungarian poet, Gabor Lanczkor has translated his new poems on Tagore in Hungarian for a special volume "Architecture of Alphabets". Select cantos of the Hungarian translation of 'Banaras and the Other' were performed by iconic Hungarian band Kaláka at the Times Lit Fest 2017 in Mumbai. He is currently working on Ayodhya, second of Banaras trilogy and his non- fiction book 'Biharis' (forthcoming, Aleph Books). He is co-founder of Indian Novels Collective to bring classic novels of Indian Literature to English readers and curates popular TLF (TISS Literature Fest) and Rajni Kothari lecture series in Mumbai. Ashwani is also a visiting fellow at leading global universities and think tanks including London School of Economics, German Development Institute, Korea Development Institute, University of Sussex, etc. His other books include "Community Warriors" (Anthem Press, 2008), "Power Shifts and Global Governance "(Anthem Press, 2010) and "Migration and Mobility" (forthcoming, Routledge, 2020). And he is one of the chief editors of LSE's prestigious publication "Global Civil Society: Poverty and Activism" (Sage International, 2010). He also writes a regular book column in Financial Express. In his leisure, he repairs Derrida's punctured cycle, and makes Bihari Litti- Chokha crooning 'Ooh La, La Ooh La, La Tu Hai Meri Fantasy'! He can be contacted at ashwanitiss@gmail.com

\section{Q. What's your relationship to English language?}

Note: This is an interview and there is no citation or works cited required. It is a live interview taken by Sreetanwi Chakraborty, Chief-Editor of Litinfinite Journal. 
Litinfinite Journal

ISSN: 2582-0400 [Online]

CODEN: LITIBR

Vol-2, Issue-1 ( $2^{\text {nd }}$ July, 2020)

Page No: 54-61

DOI: 10.47365/litinfinite.2.1.2020.54-61

Section: Interview

A: In a schizophrenic twist, I learnt English "language skills/from rats, reptiles, insects and part time/teachers with plastic accents". ("Banaras and the Other"). This helped me migrate across horizontal geographies of alien languages, and dream about speaking in many tongues. I am sure you won't believe I loved James Bond's car chases in my adolescent years, and enjoyed playing with rubbertoys of Lenin, Stalin and Che Guevara in the Saranda forests in the bordering areas of OdishaBengal- Jharkhand. I am aware it is not my mother's language. For some, English might be colonial slime but it has also become my language in which I return to you when my tongue feels stiff from being silent.

\section{Q: What is your opinion about the current trend in Indian English poetry?}

A: Though the footprints of urban middle-class aesthetics are still very visible, but the contemporary English poetry in India is no longer the 'poetry of the landless minority.' Also, I don't think that India poets in English are 'strugglers in the desert' as Arvind Krishna Mehrotra had noted in his widely acclaimed The Oxford Indian Anthology of Twelve Modern Indian Poets. Indian English poetry is like Girls Are Coming Out of the Woods of Tishani Doshi. They are everywhere, stirring insurgent desires and dreams. Admittedly, English poetry has migrated beyond Bombay to new locations, sites and destinations in Indian literature. If English poetry continues to flourish in older cosmopolitan -multilingual cities like Delhi, Calcutta, Bangalore, Madras, it has become more popular, more colloquial in vernacular towns like Hyderabad, Bhubaneswar, Bhopal, Patna, Lucknow, Shillong, Dehradun among others. It has also become a new address of feminist, dalit, and protest literature, and it has become more diasporic too. It is like what Ranjit Hoskote says 'Land is what you look for, all your life/Zameen is what you hope to find'. So, Nissim Ezekiel's subversively comical'Indian English' has become deeply rooted into Indian soil with its distinctive layers and tropes. Most importantly, the language of English has turned upon itself-cheating and chewing itself in her varied adult experiences including allusive moments of queer. I am happy to note that major contemporary and generation- next poets are more conscious of aesthetic effects of their poetry and also more sensuously engaged with the language as source of artistic excellence. In other words, English poetry in India is like mythical Puranic river 'Shubhsrava'- a young river in the abode of ancients, and Indian poets in English have reclaimed a broader secular, transnational and also translational Indian literary tradition. I am sure you are not surprised with Tabish Khair's rewriting of myth of Shakuntala as the daughter of a secular Muslim scholar in his collection Man of Glass.

Q: "It was the third day of rainbow-lust..." a line from your famous Anatomy of Baranassrey as told by Major James Rennel encapsulates fine strands of poetry deeply tinged into the colours of Indian myth and locales. How do you incorporate myths into your poems?

A: Guess,'after the third day of rainbow -lust' - the lovesick aging god/ lying on a bed of arrows/ wakes up from opiate-slumber/in the camphor clouds of sacred ambitions'. For So, in Anatomy of Baranassrey, history is more like a 'photo-dream-love play'- it is a fantasy, in part personal and political. And myths are a self-myth-making to hide my multiple heteronyms. Using the poetic device

Note: This is an interview and there is no citation or works cited required. It is a live interview taken by Sreetanwi Chakraborty, Chief-Editor of Litinfinite Journal. 
Litinfinite Journal

ISSN: 2582-0400 [Online]

CODEN: LITIBR

Vol-2, Issue-1 ( $2^{\text {nd }}$ July, 2020)

Page No: 54-61

DOI: 10.47365/litinfinite.2.1.2020.54-61

\section{Section: Interview}

of ribaldry, I deploy mythic memory to subvert-invert reality and challenge 'lies and more lies' of authoritarian time present and past. Eminent poet and thinker K. Satchidanandan believes that my world-mythic or real is "half-fantastic, and half-real, half-mythical, and half-contemporary", and it is so visual that "poems should have been illustrated by someone like Goya, if not William Blake". In short, my usage of myths is part of primal, primitive journey of language itself. If it sounds whimsy, and mischievous then I am true to myself and my poetry!

\section{Q: How has travelling contributed to your poetic art?}

A: YES my poems are about exile, displacement, dispossession and travels. But I fear travel yet I travel frequently to shed my fears. Every time that I do my travelling, I can say I experience a very short moment of death, what you can call instant execution at the hands of some death squad, a figment of imagination. I am sorry if this sounds a little dismal. And when I travel I am often unclean, and I also smell like a dead parrot fish. I am unable to hear the sound of rustled leaves or see faint early- morning shimmer from the snow -capped mountains. I see nothing when I travel because my eye sockets generally get affected by lead and mercury. For me, travel is a fantasy collage of histories, myths and memories of naked powerful men smeared with volcanic ashes all over their bodies, and different versions of rogue women I have never met; it's actually an autobiographical journey of the poet into a new realm and language of words- monosyllabic to polysyllabic words arranged in neat rows of different coloured toothbrushes in red, violet and pink, in my bathroom. With which you feel like brushing your dirty-crooked teeth!

Q: Indian poets in English are often more focussed on Western Europe but yours are widely published in Hungary. What's your relationship to Hungary and your experience of working with the award-winning Hungarian poet and novelist Gábor Lanczkor ?

Answer: I met Gábor Lanczkor accidentally in Delhi. He loved "My Grandfather's Imaginary Typewriter", and I fell in love with his 'original underpainting' of Amrita Sher-Gil. Thereafter, he took my 'Banaras' all over Hungary including finding a home for my poetry at Kaláka concert, the world-renowned Hungarian ensemble. With the help of poet-friend Hemant Divate, we brought his 'Sound Odyssey-Selected Poems to India. So, it is truly transnational-translational experience. Believe it or not, Gabor showed me in Budapest "the thick forest of Vrindavan/ where riverside bushes/ are woven into a pastoral" (From Gabor's poem "Colour is my Domain"). And I also woke up "in the middle of the night/to Freud, Nietzsche and Attila József/discussing the alternating fortunes of solar energy/and welcoming rich, elderly eastern ladies at the hotel reception". (From my poem "Hotel Budapest, published in Hungarian journal 1749). It is amazing how you climb unknown peaks with 'the egg of a Ural owl in your pocket'. Significantly, Gábor expanded my post-colonial poetic imagery beyond usual colonial gaze of Western Europe. Diverse poetic and political traditions of Eastern Europe especially Balkan region have made my poetic journey a more non-English surreal text. Illusory, hypnotic quality of storytelling and mathematical experiments of a contemporary generation of Hungarian poets have lent my poetry a new "architecture of alphabets" in Hungarian. No wonder, 'Amrita Sher-Gil the Indo-Hungarian painter's mother reads my poems at Gellért Hill and 'for long you palpate like the wet surface of star-like moss' in Budapest'.

Note: This is an interview and there is no citation or works cited required. It is a live interview taken by Sreetanwi Chakraborty, Chief-Editor of Litinfinite Journal. 
Litinfinite Journal

ISSN: 2582-0400 [Online]

CODEN: LITIBR

Vol-2, Issue-1 ( $2^{\text {nd }}$ July, 2020)

Page No: 54-61

DOI: 10.47365/litinfinite.2.1.2020.54-61

Section: Interview

Q.What's your relationship to Tagore? In the Hungarian volume of 'Architecture of Alphabets', your poems are collaged with Tagore's verses. And you have done readings in lake side town Balatonfüred where Tagore spent few weeks on his way to recovery from cardiac stroke in October 1926.

A: Tagore is real and surreal for me. I would have died of dehydration without Tagore's verses, and his novels and stories. I was born in the backyard of Tagore's home town and learnt spoken words of my language from Tagore's donkey Columbus. Tagore logged me as a poet and made me realise the futility of war and nationalism. I don't believe it -people say I resemble Tagore. Over time, I have become a Tagore impersonator. No wonder, I am running away from his old assassins. Helicopter blades whirring, I repeat what Tagore told me on the run "Howrah Bridge is a woman/And Kolkata has become an old alarm clock. /We are poets/We are biology/W(e) are evolving... (from my poem "Tagore Teaching Evolutionary Biology in Howrah")I can't believe meeting 'Tagore', and smoking Panama cigarette with him in Baltonfured. I must say every Bengali must travel to Lake Baltonfured to regain life and youth. Send me a postcard without postage stamp if you wanna know more about a Tagore or me in Budapest or Baltonfured.

\section{Q: Tell us something about your book Community Warriors.}

A: This is quite like my poem "monologues of a selfie"- ha ha. Yup. You got it right. This is my most famous and most popular non-fiction book on violence of private caste militia in the Indian state of Bihar. Based on more than a decade of research while I was doing my doctoral degree at Oklahoma, the book was published by Anthem Press (London). I am told by my colleagues, researchers and students that this is an "iconoclastic exposition of contemporary reality of Bihar". Delighted that this book is still fresh in the memory of people even after a decade of its first print and it is used as a primary reference material for anyone researching caste militias, predatory politicians, Maoist revolutionaries, brutal landlords, peasants and other subalterns in a land characterized as much by its "feudal" social structures as by immense political vitality. So, read it for poetics of violence and resistance. I am working on a sequel to Community Warriors, so wait for more poetry from the underworld of violence!

\section{Q: What's your relationship to Pop culture or performance poetry?}

Answer: Before becoming a poet, I was a I was a map-maker, meat-packer, fruit-picker and occasionally a night -guard at the grand hotel Budapest in Mumbai. Now, I am leading ridiculously eerie, popular, and ultra-realistic digital life of Simba in the "Lion King". Ha ha. "You know Kai Miller - that Jamaican poet. He loves singing DUP-DUP-dudududuDUP-DUP.Don't tell me a reason why you like it. Just sing DUP-DUPdudududu-DUP-DUP.Oh, life is so beautiful these days. Me, Me, Me, Me Only Me. It is queer. Downright queer. Are you still not convinced? That's O.K. Good news. Any doubts ...loving performance poetry, as long as you can love it - believe me we have come to enjoy and consume anything, everything!

\section{Q: Tell us something about your engagement with the Indian Novels collective.}

A: Translations are million-tongued conversations in the extended family of languages - gossiping, quarrelling, and brokering peace among unfaithful lovers. Translations are often in-travel mode,

Note: This is an interview and there is no citation or works cited required. It is a live interview taken by Sreetanwi Chakraborty, Chief-Editor of Litinfinite Journal. 
Litinfinite Journal

ISSN: 2582-0400 [Online]

CODEN: LITIBR

Vol-2, Issue-1 ( $2^{\text {nd }}$ July, 2020)

Page No: 54-61

DOI: 10.47365/litinfinite.2.1.2020.54-61

Section: Interview

meandering and migrating across contexts and cultures. For me, translation is not a handicap. It is a mode of speech" and when a whole people start speaking a translated language -in-translation it becomes their mother-tongue. So, we all dwell in translation and are co-ethnics in this sense. In other words, we can neither dream or imagine literature without translation( real or metaphorical) This has led me to co-found Indian Novels Collective (INC)- a translation initiative to bring classic novels of Indian Literature to English readers and popularize readings and performances from Indian Literature. Over the last two years, the Collective has commissioned three novels in Hindi, Bengali and Marathi and released booklists on five languages in consultation with its mentors who are experts on the said languages. Besides hosting readings and performances at various literature festivals, bookstores and offbeat cultural venues, the Collective has an active digital presence gently nudging the younger generation to explore translated literature. You can explore our events section or blog on at the portal of Indian Novels Collective (INC)

Q: Litinfinite is a bilingual journal that publishes academic research articles, stories, poems in English and Bengali. Do you have any message for our readers?

A: For younger and aspiring writers: you can't write wearing sacred threads of your life and languages. Look for sounds of meeting, mating rivers in the imaginary words. And stay true to yourself. When you feel you can't write, you do what my imaginary Aunty Maria would do- "after a shot of white rum punch, she would often sing in foreign accent-Picotante, paralysante...picotante, paralysante”. (From 'About Aunty Maria' poem). And your journal Litinfinite is luminous, sensuous and, chocolicious; an addictive literary treat you could ignore at your own peril. Congratulations!

\section{Ashwani Kumar Poems}

\section{(1)Life of a Cosmic Fish}

Whether we like it or not

Walking through infinite light in the shark's

Tunnel, we are all overwhelmed with a bitter sense

Of frailty and vulnerability.

I don't know if you know-

Life has no future because

Immortality is a door to eternity,

A garment overpriced.

Everything in the fast-expanding universe

Has a price.

There is nothing left in the end,

But death does not vanish with everything.

You can simply step out of your body

Look into the mirrors in your office,

Note: This is an interview and there is no citation or works cited required. It is a live interview taken by Sreetanwi Chakraborty, Chief-Editor of Litinfinite Journal. 
Litinfinite Journal

ISSN: 2582-0400 [Online]

CODEN: LITIBR

Vol-2, Issue-1 ( $2^{\text {nd }}$ July, 2020)

Page No: 54-61

DOI: 10.47365/litinfinite.2.1.2020.54-61

Section: Interview

Planning permanent posthumous fame

In the cities of iron, silver and gold.

You know this is not your life,

But a giant number

Shining in the mathematical

Moment of decaying.

Our ancestors have given us

Several craters in our bodies for dwelling of

Sinners and saints. For making love with

Age-less peacocks and grasshoppers.

You can't imagine the strength of a butcher

Unless you offer your own neck

To his chopping blade. I wonder

If the truth of the death is known to you

You were you; I was you

Holding wooden shopping bags,

and smoking light darkness-

A trail of void rising up in the eye of a fish!

( Dedicated to the loving memory of my beloved lawyer and activist friend Jeetendra Roy who passed away in Patna, Jan2020)

\section{(2) La Conversation: Prisoner 24601}

Speak Bengali in French accent,

$\mathrm{Ah}$, it is impossible.

I don't like hitch-hike with vowels.

Forgive me for asking

Where was Macbeth?

(Awkward silence)

My cousin.

Oh, he was learning primitive designs

Of white marble- tomb in Hiroshima-Nagasaki.

You travelled to Rangoon on yellow passport.

Yes.

Did you kill Halloween ghost?

Yes.

Perfect.

But tell me.

Note: This is an interview and there is no citation or works cited required. It is a live interview taken by Sreetanwi Chakraborty, Chief-Editor of Litinfinite Journal. 
Litinfinite Journal

ISSN: 2582-0400 [Online]

CODEN: LITIBR

Vol-2, Issue-1 ( $2^{\text {nd }}$ July, 2020)

Page No: 54-61

DOI: 10.47365/litinfinite.2.1.2020.54-61

Section: Interview

Why did't you murder Ramchandra Godse?

Shit.

MI agents double -crossed me.

What?

They gave me wrong itinerary.

You miss dark chocolates here.

Yes.

I don't like reading newspapers on I-phone.

Sorry to hear this.

I am serious

Toilet papers leave scars in the cold winters.

Really?

Don't worry,

Soon, you shall be signed off.

Oh, finally, spring-everyday- somewhere.

'Death, thy servant, is at my door'-

Said Monsieur Tagore.

(Prisoner 24601 is a reference to Jean Valjean- the protagonist of Victor Hugo's novel 'Les

Misérables' who was arrested for stealing bread to feed his starving sister's children. Bahadur

Shah Zafar, the last moghul ruler was sent in exile to Rangoon after 1857 mutiny.

Ramchandra Godse, popularly known as Nathuram Godse assassinated Mahatma Gandhi. And 'Death, thy servant, is at my door' is quoted from Rabindranath Tagore's Gitanjali)

\section{(3)Satyagraha}

In the smoky-wooden corner of your eye-lid

I agitate like a wounded blue-whale

And the sea erases the wrinkles of the past atrocities.

Gathering slowly in your imperial brows

In the word-less lightening

I speak the voices of prisoners and slaves

And ride the broken toy cycle like an aging boy in Sabarmati.

In the untimely violence of seasons

I drown in the sorrows of charred -wheat -fields

And feed the hungry with mountain of breads.

There are only truths and beauties

In the soft, insurgent music of prayer-

Sprouting furiously in the felled trees of Aarey Colony

I am near and now

Weaving invisible fabrics of everyday satyagraha

And singing with poet- revolutionaries in chorus

Ishvar Allah tere nam sabko sanmati de bhagwan-

May Allah Bless you all in your name...

Note: This is an interview and there is no citation or works cited required. It is a live interview taken by Sreetanwi Chakraborty, Chief-Editor of Litinfinite Journal. 
Litinfinite Journal

ISSN: 2582-0400 [Online]

CODEN: LITIBR

Vol-2, Issue-1 (2 $\left.2^{\text {nd }} J u l y, 2020\right)$

Page No: 54-61

DOI: 10.47365/litinfinite.2.1.2020.54-61

Section: Interview

\section{Suggested list of reading:}

Kumar, Ashwani. BIHARI- A Portrait of a Community. Aleph (forthcoming).

Kumar, Ashwani \& Ram B. Bhagat. Migration and Mobilityin India: A Citizenship Perspective. Routledge (forthcoming).

Kumar, Ashwani. Banaras and the Other.Paper Wall Media \& Publishing Pvt. Limited, 2017.

Kumar, Ashwani. My Grandfather’s Imaginary Typewriter. Kozhikode: Yeti Books, 2014

Kumar, Ashwani \& Dirk Messner. Power Shifts and Global Governance Challenges: Perspectives from North and South, London: Anthem Press, 2010.

Kumar, Ashwani, Mary Kaldor et al., Global Civil Society: Poverty and Activism. London:Sage International,2009.

Kumar, Ashwani. Community Warriors: State, Peasants and the Private Caste Armies in Bihar. London/Delhi: Anthem Press, 2008.

Note: This is an interview and there is no citation or works cited required. It is a live interview taken by Sreetanwi Chakraborty, Chief-Editor of Litinfinite Journal. 